\title{
5 \\ CONTEMPORARY CONFLICT AND POLITICAL VIOLENCE IN THE LEVANT
}

\author{
Benedetta Berti
}

In its contemporary use, the term "Levant" commonly refers to the eastern Mediterranean countries of Israel, Jordan, Lebanon, Syria, Palestine, ${ }^{1}$ and, in some accounts, Iraq (see Figure 5.1). Its territory rests at the center of the Middle East, itself characterized by great geostrategic importance due to its natural resources - chiefly oil and natural gas - and its location at the crossroads between Africa, Europe, and Asia, which contributes to its political and military significance.

In the post-World War I period, European colonial powers drew the national borders of the countries that make up the Levant. This externally driven state-building process contributed to the rise of unstable and fragile countries and, in some cases, conflict and violence.

This chapter offers a brief introduction to an especially complex and diverse region of the world. It briefly assesses the Levant's historical, geographic, and political significance while also providing a concise political overview of the main countries that make up this part of the Middle East. The chapter then examines the contemporary history of political violence in the region, specifically the ArabIsraeli conflict and the impact of internal violence and civil wars. In accounting for the region's conflict dynamics, the chapter emphasizes the role played by non-state armed groups, focusing specifically on the development of Hamas and Hezbollah, two of the most prominent armed political movements active in the Levant.

\section{Framing the Levant}

The Levant holds a rich historical legacy. Mesopotamia — the lands between the Tigris and Euphrates rivers-is an integral part of the Fertile Crescent and is often referred to as the cradle of civilization. ${ }^{2}$ From the establishment of the world's first cities to the development of written legal codes and early systems of governance, the early history of mankind is intrinsically linked to the Levant. ${ }^{3}$ Just as importantly, the birth and development of both Judaism and Christianity occurred along the southern shores of the Eastern Mediterranean, while the Levant was later central to the evolution and growth of Islam and early Islamic civilization. ${ }^{4}$

The Levant is home to approximately 80 million people-with Iraq and Syria being the two most populous states. ${ }^{5}$ An important demographic characteristic is the high percentage of young people. Approximately $53 \%$ of the population is 24 years or younger, a trend commonly referred to as the "youth bulge." ${ }^{6}$ 


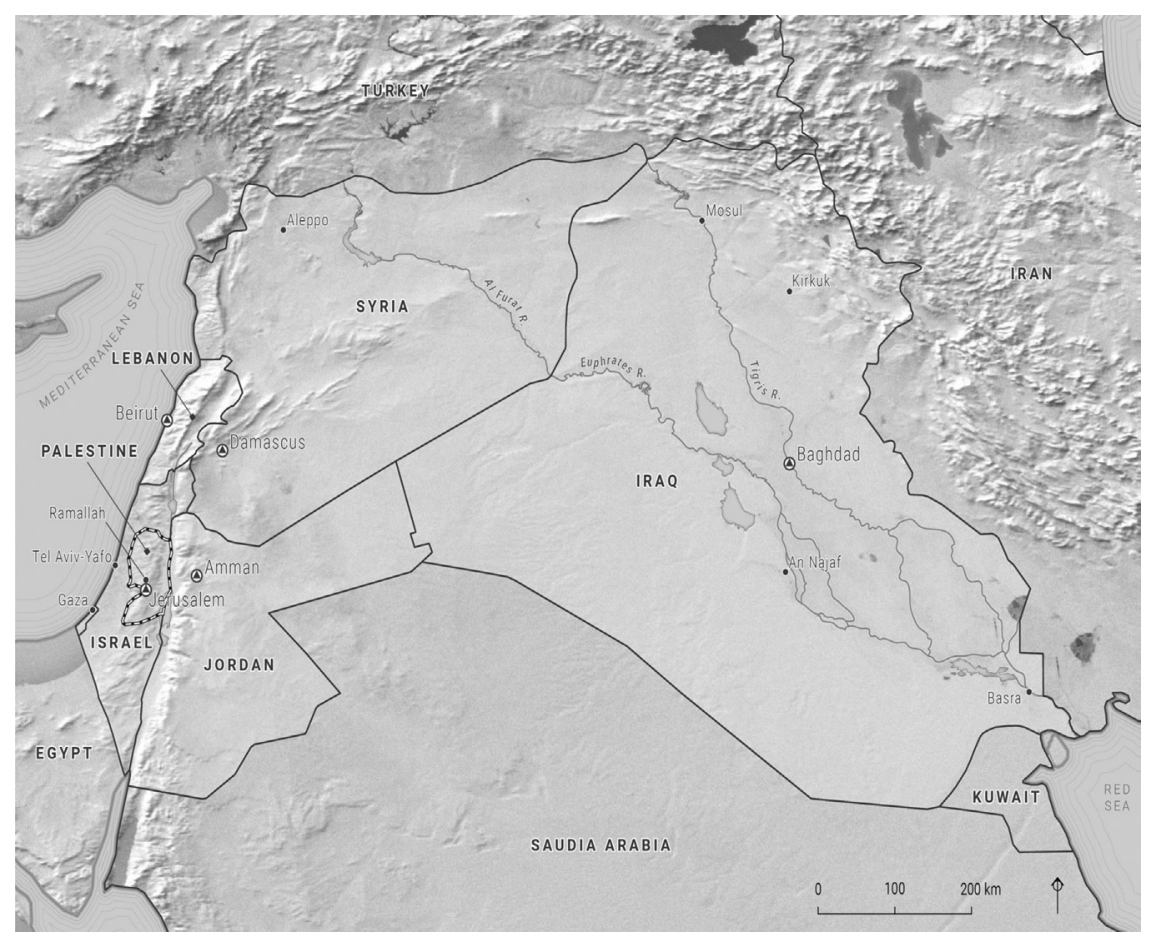

Figure 5.1 Countries constituting the Levant

The Levant is diverse religiously, linguistically, and ethnically. The majority of the population is Sunni Muslim, and Sunni Islam has deeply shaped the region both historically and culturally. There are, however, important exceptions. Approximately $60-65 \%$ of Iraq is Shia Muslim, while roughly three quarters of the population in Israel is Jewish. ${ }^{7}$

Sizeable religious minorities and Islamic sub-sects have historically been present in the Levant, including Druze communities across Israel, Lebanon, and Syria; Alawites in Syria; and Christian minorities in all the countries of the region. The majority of the population is Arab, and the largest non-Arab populations are Jews in Israel and Kurds between Syria and Iraq (as well as in Iran and Turkey). ${ }^{8}$

Lebanon is itself characterized by great diversity - recognizing 18 different religious, ethnic, and sectarian groups-but it is dominated by three main confessional groups: Maronite Christians, Sunni Muslims, and Shia Muslims. ${ }^{9}$

\section{State formation and development in the Levant (1916-1948)}

External nation-states - and especially the European colonial powers- had an inordinate impact in shaping the current political order in the Levant. Although the role and influence of Western powers dates further back to the 19th century, the current state-based order came into existence in the post-World War I period on the ashes of the Ottoman Empire.

The Ottomans, from their seat in Istanbul, had ruled over the lands of the modern-day Levant for more than 400 years, eventually establishing a flexible system of local administration. The Ottomans not only often preserved local customs and power structures, but they granted a level of autonomy to different religious communities in the region. ${ }^{10}$ 
The Levant's political landscape changed dramatically after the Ottoman Empire's fateful decision to side with Germany and Austria in World War I. The Ottomans' military defeat in the war worsened its decline and precipitated its final collapse. On the ruins of the once glorious empire, victorious European powers - specifically, France and the United Kingdom-established spheres of control over the Levant and in the process began to draw borders and establish new states.

The foreign powers' geostrategic interests largely shaped this externally imposed process. Accordingly, policies such as including local actors in decision-making, or establishing strong and legitimate states, were low on the European powers' list of priorities for the region. The Sykes-Picot Agreement, authored in 1916 by British official Mark Sykes and his French counterpart Francois Georges-Picot, was central to the formation of the modern-day Middle East. In this document, the two diplomats essentially distributed the Levant between France and the United Kingdom. ${ }^{11}$

The Sykes-Picot Agreement, with some amendments, served as the basis for the post-World War I distribution of power expressed through the League of Nations' mandate system. Former Ottoman lands were divided into mandates and distributed between France, which was assigned the lands corresponding to present-day Syria and Lebanon, and the United Kingdom, which was allocated the mandates of Iraq and Palestine $^{12}$ (later divided into two areas, Palestine and Transjordan). ${ }^{13}$ The mandate concept stipulated that each territory would be ruled on an interim basis with a commitment by the mandatory power to "guide" those states toward their own independence.

\section{Lebanon and Syria}

France shaped the formation of Lebanon and Syria, including their border demarcations. France's desire to recognize the Maronite Christian minority's claims to statehood led to the rise of the Lebanese state. ${ }^{14}$ To fulfill those aspirations and to make the new Christian protectorate viable and independent, the French administration expanded the territory of this proto-state beyond the Christian-dominated Mount Lebanon area, incorporating coastal areas from Tyre to Sidon, Beirut, Tripoli, and the Bekaa Valley. ${ }^{15}$

Present-day Lebanon thus emerged in the 1920s as "Greater Lebanon," changing its name in 1926 to the Lebanese Republic and finally obtaining independence from France in $1943 .{ }^{16}$ Yet with the expansion beyond Mount Lebanon, the new state effectively abandoned the possibility of becoming a Christianmajority country and emerged as a multi-confessional state, dominated by three main sectarian groups: Maronite Christians, Sunni Muslims, and Shia Muslims.

Lebanon's political system developed around this dynamic, regulating the polity on the basis of the principle of power-sharing between the country's distinct communities and establishing Lebanon's unique sectarian system, which allocates a fixed quota of high political posts and parliament seats to each confessional group according to their estimated size. Since then, Lebanon has over time repeatedly struggled to find a stable resolution to its sectarian divisions, a normalization of its inter-community relations, and a formula to ensure cohesive and strong central political institutions.

France also oversaw the administration of Syria, although it faced significant local resistance. It tinkered considerably with the political system, experimenting with the notion of a federation and with the idea of maintaining separate statelets for Syria's main ethnic-religious minorities, such as the Druze and Alawite communities. ${ }^{17}$ Eventually, however, a centralized Syrian state emerged and gained full independence in 1946.

The end of the French mandate in Syria did not spell the end of Syria's troubles. In subsequent years, Syria faced extreme internal instability and volatility, marked by a series of internal conflicts, coups, and counter-coups. After a brief and largely failed experiment to form a political union with Egypt in 1958, Syria's path toward "authoritarian consolidation" began in the early 1960s with the rise to power of a group of military officers hailing from a current of the secular-nationalist Baath Party. This process eventually led 
to the ascent of Alawite military officer Hafez al-Assad, along with that of an Alawite military-political elite, leading to a period of stable yet deeply authoritarian rule. ${ }^{18}$

During his years in power as the president of the Syrian Arab Republic from 1971 until his death in 2000, Hafez al-Assad relied on a combination of repression and co-optation to ensure his permanence in power, maintaining a strong grip on all government institutions and on Syria's highly coercive security apparatus. ${ }^{19}$ After his death, the presidency passed to his son Bashar al-Assad, who ruled largely uncontested until the beginning of the Syrian revolution in 2011 - a watershed event that challenged the regime and precipitated the country's descent into a protracted and bloody civil war.

\section{Iraq, Jordan, Israel, and Palestine}

The other mandatory power, the United Kingdom, became just as involved in the process of state formation, resulting in the creation of Iraq, Jordan, Israel, and the non-establishment of a Palestinian state.

Iraq emerged out of the three Ottoman provinces of Basra, Baghdad, and Mosul, which Britain consolidated into one multi-ethnic and multi-sectarian state characterized by an Arab-Shia majority and two sizable Arab-Sunni and Kurdish (largely Sunni) minorities. ${ }^{20}$ After becoming the mandatory power in 1920, the British backed the ascent of the Hashemite dynasty under King Faisal to ensure influence over this complex territory even after Iraq obtained independence in 1932.

The Hashemite family's rise to power in Iraq was itself a byproduct of Britain's regional power games. Hailing from the Arabian Peninsula and acting as sharif (custodians to the holy cities of Mecca and Medina), the Hashemites had allied with Britain against the Ottoman Empire, leading to what came to be known as the Arab Revolt of 1916-1918. ${ }^{21}$ The British-Hashemite alliance had been forged based on the expectation that the United Kingdom would support Emir Husayn ibn Ali's political plans to establish a united Arab state to rule the Arab provinces of the Ottoman Empire, from Palestine to Iraq and from the Mediterranean Sea to the Arab/Persian Gulf. ${ }^{22}$

British support, however, was short lived. The Hashemites only succeeded in ruling over a portion of their desired lands. They briefly took control of Damascus before France, backed by Britain, evicted them in $1920 .{ }^{23}$ In the following years, the Hashemites not only saw their hopes for a united Arab state fade away, but they also eventually lost the struggle for control of the Arabian Peninsula to the al-Saud family, which would later consolidate its power and give rise to modern-day Saudi Arabia where they continue to rule today. In this context, Iraq became a consolation prize awarded to the Hashemite family despite their lack of strong local roots or support.

The Hashemite family's reign in Iraq would last until 1958. To rule over what was essentially an unfamiliar country, the monarchy entrenched a system of governance that strongly relied on the Sunni minority to control the key political and military posts, largely marginalizing other parts of Iraqi society. A military coup in 1958 eventually overthrew the Hashemites, precipitating a decade of instability.

This lasted until 1968, when the Baath Party rose to power under the leadership of Ahmad Hasan alBakr and Saddam Hussein. ${ }^{24}$ Much like the case of Syria, during the following decade, Saddam Hussein emerged as a strong, secular, nationalist, socialist, and deeply despotic ruler. He eventually assumed control of the presidency and ruled Iraq between 1979 and 2003, until his regime was brought down following the U.S.-led invasion of the country.

On the other side of the Levant, the British role was just as central in the birth of the modern-day states of Jordan and Israel, as well as in shaping the beginning of what would later be known as the Arab-Israeli conflict (or the Israeli-Palestinian conflict).

As the mandatory power, Britain separated the Palestine territory into two separate areas-Palestine and Transjordan - with the latter encompassing the lands on the eastern banks of the Jordan River. This 
territory, oddly and artificially shaped between Israel-Palestine, Syria, Iraq, and Saudi Arabia, was to be ruled first as the Emirate of Transjordan and then, after 1946, as the Hashemite Kingdom of Jordan — serving essentially as an additional compensation prize, in addition to Iraq. ${ }^{25}$

During the next three decades, King Abdallah I of the Hashemite dynasty consolidated the crown's power over the new kingdom by building strong relationships with prominent tribal families and with key power-brokers hailing from the East Bank of the Jordan River. ${ }^{26}$ Thus, while the monarchy in Iraq did not stand the test of time, its counterpart in Jordan thrived, with the crown still in power today.

The Kingdom of Jordan extended its borders following the 1948 war against the newly formed state of Israel, with Jordan gaining control over the areas of Palestine known as the West Bank, stretching to East Jerusalem. As a result, Jordan altered its demography and became a country of both "east-banker" Jordanians and "west-banker" Palestinians, with separate political and national identities. ${ }^{27}$ Even though Jordanian control over the West Bank ended in 1967, the country's social basis was forever transformed.

In addition to establishing Transjordan, Britain's role would be consequential in shaping the future of mandatory Palestine. The Sykes-Picot Agreement of 1916 had already recognized the interests of the United Kingdom over the lands corresponding to present-day Israel and Palestine. British policy in mandatory Palestine took shape in those years.

On the one hand, the United Kingdom developed a favorable attitude toward the possibility of seeing a Jewish settlement and the development of a "national home" for the Jewish people in Palestine, influenced by advocacy from the emerging Zionist movement in Europe. This policy was expressed in the famous 1917 Balfour Declaration. ${ }^{28}$

On the other hand, as the direct ruler in mandatory Palestine, Britain also had an interest in preventing mass-based unrest and conflict in the areas under its control. Britain soon discovered that finding a balance between these two interests was not simple, as supporting the Zionist movement in Palestine produced consistent local opposition from the Arab majority on the ground, resulting in unrest, protests, and tensions. ${ }^{29}$

During the 1920s and 1930s, a series of local rebellions put the "Palestine question" high on the British foreign policy agenda. Britain initially took distinct options into consideration during the 1930s, including the idea of partitioning the land to solve the struggle between the Jewish and Arab national movements. Yet by 1939 , the country opted to restrict Jewish immigration and appeared to move toward placing the idea of a Jewish State on indefinite hold. ${ }^{30}$

These policy changes did not, however, produce a more stable situation for the mandatory power. Instead, they led to active armed struggle by Zionist non-statutory armed groups against the British presence in mandatory Palestine. These groups employed a strategy based on sabotage, guerrilla warfare, and, in some cases, terrorism.

The operational tempo of anti-British operations further escalated in the immediate aftermath of World War II, along with the unrest between Arab and Jewish communities on the ground, contributing to the mandatory power's decision to refer the "Palestine question" to the newly formed United Nations. With the notion of a Jewish State gaining fresh momentum after the end of the war, the United Nations endorsed the idea of the partition of mandatory Palestine, a decision also shaped by the tragedy of the Holocaust.

This process eventually led to the end of British rule over Palestine and to the United Nations General Assembly's adoption of Resolution 181 in November 1947, recommending a partition plan that would establish both a Jewish and Arab state in mandatory Palestine. ${ }^{31}$ While leaders of the Zionist movement and the Jewish communities in Palestine cheered the decision, it triggered widespread protests within the Arab population, as well as vehement rejection from the established Arab states in the region-precipitating the 1948 Arab-Israeli War. ${ }^{32}$ 


\section{Contemporary political violence in the Levant before the Arab Spring}

The process of state formation in the Levant is intrinsically related to foreign intervention, violence, and conflict. This legacy continued to shape political dynamics in the region long after the colonial powers' direct control waned and the states emerged as independent countries.

For example, the post-independence process of authoritarian consolidation in both Syria and Iraq between the 1950s and 1960s was fraught with internal violence, coups, and uprisings. Under Saddam Hussein in Iraq, the country went to war twice, first against the newly established Islamic Republic of Iran between 1980 and 1988 and then again in the 1990-1991 Gulf War. The Gulf War led to Saddam Hussein's defeat and to more than a decade of international sanctions placed on the Iraqi regime. ${ }^{33}$ Elsewhere in the Levant, Lebanon's fragile sectarian system would produce two civil wars in 1958 and between 1975 and 1989.

At the same time, the other dynamic that helps explain the past decades of political violence and war in the Levant-both conventional/inter-state and non-conventional/intra-state violence-is the Arab-Israeli conflict.

Israel's contested independence inaugurated two-plus decades of regional conventional wars between the state of Israel and its Levantine as well as Middle Eastern neighbors. Following the adoption of Resolution 181 that partitioned Palestine into Arab and Jewish states, armed confrontation ensued between the Arab and Jewish populations in mandatory Palestine. These clashes became a fully fledged regional war following Israel's proclamation of independence in May 1948, leading military units from Egypt, Transjordan, Lebanon, Syria, and Iraq to invade the newly born state under the umbrella of the Arab League. ${ }^{34}$

The war concluded with a series of armistices in 1949, leaving the situation on the ground profoundly altered: Israel managed to withstand the attacks and expand its territory, Transjordan advanced to take control of the West Bank of mandatory Palestine and parts of Jerusalem (including its old city), and Egypt gained the region of mandatory Palestine known as the Gaza Strip. ${ }^{35}$ Israel viewed the 1948 war as a victorious fight for independence, whereas the Palestinian population saw it as their nakba (catastrophe), depriving them of an independent state and making many of them stateless and refugees within the Levant. ${ }^{36}$

After 1949, the conflict between Israel and its neighbors was never fully resolved. Open hostilities resurfaced in the 1956 Suez Crisis, which pitted Israel against the Egyptian regime of Gamel Abd al-Nasser within the broader context of the Cold War. The regional tensions gradually built until an explosive war in 1967. ${ }^{37}$ The June 1967 war-also known as the Six-Day War-involved another conventional confrontation between Israel and its neighbors. The brief hostilities, ending with a United Nations-brokered cease-fire, led to an overwhelming Israeli victory, with the country taking over the Jordanian-controlled West Bank and Jerusalem, the Egyptian-administered Gaza Strip and Sinai Peninsula, and the Syrian region of the Golan Heights. ${ }^{38}$

These military achievements were yet again challenged in October 1973 when an Egyptian and Syrian surprise attack managed to taint Israel's reputation of military invincibility. Egypt and Syria sought to retake the Sinai Peninsula and the Golan Heights. Yet after early gains, the October War (also known as the Yom Kippur War or the Ramadan War) turned in favor of the Israeli military. When the conflict ended abruptly through a U.S.-USSR-brokered cease-fire agreement, Israel's control of the territories acquired in 1967 was all but unchallenged, while its opponents were deeply on the defensive.

The 1973 war concluded this period of conventional inter-state wars waged in the context of the ArabIsraeli conflict and opened the door to the beginning of a diplomatic process between Egypt and Israel, resulting both in Israel's withdrawal from the Sinai Peninsula as well as a peace treaty between the two states in 1979. 


\section{Irregular warfare, insurgency, and terrorism in the Levant}

Whereas 1948-1973 marked a period of conventional wars linked to the Arab-Israeli conflict, the following decades brought a shift to a series of unconventional confrontations pitting mostly the Israeli state against non-state actors waging war on behalf of the Palestinian people, often using terrorism as a tactic.

This shift resulted from the dramatic political and military defeat inflicted to Arab states and their leaders-who, until then, aspired to represent the Palestinian cause - in the 1967 war. $^{39}$ A new generation of Palestinian political and military leaders also proved instrumental to these changes, especially through the creation of Fatah - under the leadership of Yasser Arafat — and by working to increase the autonomy of the Palestine Liberation Organization (PLO) ${ }^{40}$

The shift began gradually, first with Palestinian armed units - known as fedayeen — undertaking hit-andrun, cross-border operations against Israeli targets, chiefly from Jordan and, to a lesser extent, from Syria and Egypt. ${ }^{41}$ After 1967, an insurgent strategy based on terrorism and guerrilla warfare became the backbone of the Palestinian armed strategy, with the PLO leading a "war of attrition" inspired by the National Liberation Front in Algeria. ${ }^{42}$

In parallel, the PLO began relying on "publicity terrorism" in the international arena, including hijacking civilian airliners or assassinating Israeli officials and civilians abroad. These tactics served the strategy of putting the Palestinians front and center as a global issue and to elevate the status and power of the PLO and its leaders. ${ }^{43}$ Internationally, the strategy was successful, consecrating the rise of Arafat and the PLO as the sole legitimate representative of the Palestinian people, a status endorsed by the Arab League in $1974 .^{44}$

The PLO's unconventional tactics employed against Israel led to internal tensions within the countries from where they operated. Regional governments that harbored Palestinian militants increasingly resented the PLO's autonomy and freedom of action, as well as the Israeli counterattacks against the PLO on their own territory. A dramatic example of this dynamic occurred during the 1970 conflict between Palestinian armed factions and the Jordanian army, known as "Black September." On that occasion, violent clashes between the Jordanian government and the PLO led to the latter's permanent ouster from Jordan. ${ }^{45}$

Lebanon, where the PLO relocated after its expulsion from Jordan, represents another example of the negative impact Palestinian armed operations had on the host country's stability. Indeed, in the 1970s, the double impact of the PLO's armed struggle in southern Lebanon and Israeli counterattacks only contributed to the further militarization and destabilization of Lebanon, eventually contributing to the country's descent into a prolonged civil war between 1975 and 1990. ${ }^{46}$

The Lebanese civil war quickly became a proxy war, with extensive regional and international involvement. Israel, for example, intervened militarily in Lebanon in 1978 and 1982. The 1982 operation, dubbed "Operation Peace for Galilee," went well beyond the objective of eliminating the PLO's presence from southern Lebanon. Israel became involved in Lebanon's civil war and eventually established a "security zone" in southern Lebanon, an area that would be controlled by the Israel Defense Forces (IDF) until its withdrawal in $2000 .{ }^{47}$

By the time the civil war ended in 1989, the PLO had lost its strong operational base, and Lebanon was de facto divided, with the "security zone" under IDF control and the rest of the country under strong Syrian control. After the war, the Syrian government became- under the terms of Lebanon's internationally brokered peace agreement- the official "guarantor" of the peace, a role the country used to consolidate its military and political influence over Lebanon until 2005..$^{48}$

After Lebanon, the map of conflict shifted again. In the following decades (1982-2003), Israel would be simultaneously involved in two major irregular conflicts against Hezbollah in Lebanon and against distinct Palestinian armed factions, eventually led by Hamas, in the West Bank and Gaza. 


\section{Hezbollah}

Hezbollah ("The Party of God") was officially established as an umbrella military group in the early 1980s, largely as a response to the Israeli invasion of Lebanon in 1982. The organization had the initial goal of unifying the anti-IDF military actions of armed Shia factions that had emerged in the midst of the Lebanese civil war and had found common inspiration in the 1979 Iranian Revolution and its ideals. ${ }^{49}$

With active Iranian help, ${ }^{50}$ Hezbollah's military capabilities evolved throughout the civil war, with the group relying chiefly on asymmetric tactics-including car bombings, suicide attacks, and kidnappings of Israelis and other foreigners - to implement a strategy of attrition aimed at driving Israel out of Lebanon by inflicting a high number of casualties, especially through a series of "self-martyrdom," or suicide, attacks. ${ }^{51}$

In parallel, Hezbollah's strategy also sought to expel foreign peacekeeping troops from Lebanon in the early 1980s, which led to a number of high-profile terrorist attacks, including the April 1983 suicide operation against the U.S. Embassy in Beirut and the infamous barracks bombing in October 1983 that killed 241 U.S. service personnel. ${ }^{52}$ Due to these and other operations, Hezbollah has been regarded as the armed group responsible for putting suicide bombing as a tactic on the map, leading to its more widespread adoption by other non-state armed groups in the following years. ${ }^{53}$

After 1989, with the end of the civil war in Lebanon, Hezbollah redefined its identity as Lebanon's self-proclaimed "national resistance," preserving its military apparatus and directing its military campaigns chiefly against the Israeli presence in the Israel-controlled "security zone." Hezbollah's actions triggered recurrent escalations, including the short-lived 1993 and 1996 armed confrontations. ${ }^{54}$ Hezbollah also developed its social and political outreach in the post-civil war period, becoming both an active political party involved in the Lebanese political system as well as a major welfare and social services provider for the Lebanese Shia community at large. The group still maintains these roles today. ${ }^{55}$

Following the Israeli withdrawal from the security zone in 2000, Hezbollah's military strategy began to gradually shift from high mobility to holding ground, creating a complex system of underground tunnels and bunkers and investing in more conventional training. ${ }^{56}$ These changes became especially clear in the July 2006 war with Israel, which revealed that Hezbollah had further transitioned from a non-conventional militia to a hybrid army. ${ }^{57}$

In the July 2006 war, Hezbollah effectively relied on a combination of sub-conventional and conventional tactics, including defending and holding ground, ${ }^{58}$ while also propping up its small guerrilla units with standoff weapons normally associated with conventional military forces. ${ }^{59}$ These trends have only increased since 2006, with the group growing in size, upgrading its arsenal and infrastructure, and improving its war-fighting capabilities. ${ }^{60}$

Since becoming involved in the Syrian civil war on the side of the ruling regime, Hezbollah's role has encompassed direct military support to conduct both offensive as well as defensive operations, including key artillery support to the Syrian army, confirming its hybrid warfare capabilities and its "beyond insurgency" status. ${ }^{61}$

\section{Palestinian armed groups and the rise of Hamas}

In parallel with the Israel-Hezbollah conflict, the other major theater of confrontation in the 1980s-2000s became the West Bank, Gaza, and Israel proper. Palestinian protests against Israel's presence and control over Gaza and the West Bank-territories it took over in the 1967 war-grew and eventually found a collective, political, and organized expression in the first intifada, a cycle of Palestinian popular protests centered on civil resistance, in 1987. ${ }^{22}$ The convergence between the protests in Gaza and the West Bank, and the rising international role acquired throughout the 1970s by the PLO and its chairman Yasser Arafat, prepared the ground for a political process that would take place in the early 1990s between Israel and the PLO. 
Eventually, this political process resulted in a set of agreements between Israel and the PLO commonly referred to as the Oslo Accords. The agreements established a principle of mutual recognition between the parties - with the PLO accepting the principle of a "two state solution" to resolve the Israeli-Palestinian conflict - and were intended to pave the way for a final status agreement. ${ }^{63}$ This process also led to the establishment of the Palestinian Authority as an interim political entity exercising political control over parts of the West Bank and Gaza, allowing the Palestinian political leadership of the PLO and Fatah to return to Palestine from exile. ${ }^{64}$

Hamas emerged out of the backdrop of the first intifada. Hamas, or the Islamic Resistance Movement, was officially founded in 1987-1988 during the outbreak of the first intifada. Its mission was to serve as the armed military wing of the Gaza branch of the Muslim Brotherhood. Even though the group was established with this relatively narrow mandate, Hamas evolved over the following decades into a complex and multifaceted organization, combining a political movement and a party, as well as an armed military wing and an extensive network of social service institutions. ${ }^{65}$

Hamas' status and role evolved further following the group's victory in the 2006 Palestinian Legislative Council elections and the subsequent clashes with Fatah, leading to the Hamas takeover of the Gaza Strip. ${ }^{66}$ Since 2007, Hamas has been in de facto control of Gaza. In previous decades, Hamas, much like Hezbollah, engaged in a series of direct confrontations with Israel, in the process refining its reliance on terrorism, insurgency, and also hybrid or semi-conventional tactics. ${ }^{67}$

From an operational perspective, Hamas transformed from a relatively unsophisticated violent faction perpetrating individual stabbings against Israelis to being able to carry out both large-scale terrorist attacks and rocket strikes against Israel. The group's political and military capabilities developed in the 1990s when Hamas emerged as the main Palestinian group opposing the Oslo Accords and when it relied on suicide bombings as a key element in its strategy of attrition against Israel.

Hamas' status rose further in the early 2000s with the sinking of the political process set forward by the Oslo Accords and the outbreak of the second intifada, characterized by high-profile suicide attacks in the West Bank, Gaza, and Israel. With the winding down of the second intifada and the death of historic Palestinian leader and Palestinian Authority President Yasser Arafat in 2004, Hamas' role increased further, culminating with the group's takeover of Gaza in 2007.

Since then, Hamas has simultaneously ruled Gaza while being involved in cyclical violent confrontations with Israel. In parallel, Hamas' military wing, the Izz ad-Din al-Qassam Brigades, has grown in size and capabilities. Inspired by Hezbollah's operational concept in the 2006 war with Israel, Hamas's military wing developed into a hybrid actor with sophisticated combat skills that rely more on standoff tactics - in combination with ambushes, improvised explosive devices, and suicide missions-while developing defensive tactics, including the limited holding of ground. ${ }^{68}$

\section{Conclusion}

The Arab-Israeli conflict has accounted for a large part of the conventional and unconventional inter-state conflict that has occurred in the Levant in the post-World War II period. At the same time, it is important to note that political violence in the region has by no means only been limited to the Arab-Israeli conflict. Indeed, as illustrated throughout the chapter, internal conflicts have occurred in virtually all the states that make up the Levant.

For example, Lebanon's internal conflicts are largely a byproduct of its complex internal political makeup, difficult inter-community relations, and often inadequate political institutions. Nevertheless, there is no question that strong and repeated foreign interference-including by its southern neighbor, Israel, and by Syria- have substantially contributed to internal instability during the previous decades.

In Syria, armed clashes and internal violence occurred repeatedly before the beginning of the civil war in 2011. Iraq's contemporary history even prior to the overthrow of Saddam Hussein in 2003 had been 
fraught with both internal unrest and violence, as well as clashes with other regional states. Moreover, in authoritarian countries like Iraq and Syria, a great share of political violence has been perpetrated by the state against its own citizens in the form of violent repression and crackdowns on any internal opposition.

The lens of internal instability and fragmentation, along with that of the Arab-Israeli conflict, reveals the dynamics of political violence in the Levant during the previous decades. Both issues are themselves at least partially a byproduct of the problematic and externally driven process of state formation in the region that largely began a century ago.

\section{Notes}

1 The terms "Palestine" and "Palestinian Territories" (or "Palestinian Occupied Territories") will be used interchangeably to designate the territory corresponding to the Gaza Strip and West Bank.

2 Charles K. Maisels, Early Civilizations of the Old World: The Formative Histories of Egypt, the Levant, Mesopotamia, India and China (London: Routledge, 2001).

3 Tareq Y. Ismael and Jacqueline S. Ismael, Government and Politics of the Contemporary Middle East: Continuity and Change (London: Routledge, 2011).

4 William L. Cleveland, A History of the Modern Middle East (Boulder: Westview Press, 2000).

5 United Nations Development Program, Arab Human Development Report (New York: United Nations, 2016). The data concerning Israel is collected through Israel's Central Bureau of Statistics, accessed August 23, 2017, www.cbs. gov.il/reader/cw_usr_view_Folder?ID=141.

6 Department of Economic and Social Affairs, Population Division, World Population Prospects: The 2015 Revision (New York: United Nations, 2015).

7 Central Intelligence Agency, "World Factbook: Middle East," World Factbook, accessed August 23, 2017, www.cia. gov/library/publications/the-world-factbook/wfbExt/region_mde.html.

8 Ibid.

9 Benedetta Berti, The Ongoing Battle for Beirut: The Role of Foreign Powers in Lebanon Between Old Dynamics and New Trends (Tel Aviv: Institute for National Security Studies, 2011), 18.

10 William L. Cleveland and Martin Bunton, A History of the Modern Middle East (Boulder: Westview Press, 2013).

11 Malcolm Yapp, The Making of the Modern Near East 1792-1923 (London: Routledge, 2013).

12 The province of Palestine then included modern-day Israel, Jordan, and the Occupied Palestinian Territories.

13 Yapp, Making of the Modern Near East.

14 Hafeez Malik, "Lebanon as An Experiment in Multicultural Independence," in Lebanon's Second Republic: Prospects for the Twenty First Century, ed. Kail C. Ellis (Gainesville: University Press of Florida, 2002), 14-22.

15 Kamal Salibi, A House of Many Mansions: The History of Lebanon Reconsidered (Berkeley: University of California Press, 1990).

16 Ibid.

17 Philip Khoury, Syria and the French Mandate. The Politics of Arab Nationalism, 1920-1945 (Princeton: Princeton University Press, 1987).

18 Patrick Seale, Asad of Syria: The Struggle for the Middle East (London: I.B. Tauris, 1988).

19 Ahed Al Hendi, "The Structure of Syria's Repression: Will the Army Break With the Regime?" Foreign Affairs, May 3, 2011, www.foreignaffairs.com/articles/middle-east/2011-05-03/structure-syrias-repression.

20 Charles Tripp, A History of Iraq (New York: Cambridge University Press, 2002).

21 Ibid.

22 Mary C. Wilson, King Abdullah, Britain and the Making of Jordan (New York: Cambridge University Press, 1987).

23 Tripp, A History of Iraq.

24 Kanan Makiya, Republic of Fear: The Politics of Modern Iraq (Berkeley: University of California Press, 1998).

25 Philip Robins, A History of Jordan (New York: Cambridge University Press, 2004).

26 Ibid.

27 Ibid.

28 Rashid Khalidi, The Iron Cage: The Story of the Palestinian Struggle for Statehood (Boston: Beacon Press, 2006).

29 Ibid.

30 Baruch Kimmerling and Joel Migdal, The Palestinian People: A History (Cambridge, MA: Harvard University Press, 2003).

31 Ibid.

32 Ibid.

33 Cleveland and Bunton, History of the Modern Middle East. 
34 Ibid.

35 Mehran Kamrava, The Modern Middle East: A Political History Since the First World War, 3rd ed. (Berkeley: University of California Press, 2013).

36 Nur Masalha, The Politics of Denial: Israel and the Palestinian Refugee Problem (London: Pluto Press, 2003); Benny Morris, The Birth of the Palestinian Refugee Problem Revisited (New York: Cambridge University Press, 2004).

37 Malcom Kerr, The Arab Cold War: Gamal 'Abd al-Nasir and His Rivals, 1958-1970 (New York: Oxford University Press, 1971).

38 Michael Oren, Six Days of War: June 1967 and the Making of the Modern Middle East (New York: Oxford University Press, 2002).

39 Sadik Azm, Self-Criticism after the Defeat (London: Saqi Books, 2011).

40 In 1964, the Arab League established the Palestine Liberation Organization as a representative of the Palestinian people. The PLO's role would increase after 1967, especially after Fatah movement leader Yasser Arafat assumed its chairmanship in 1969. Eventually, the Arab League recognized the PLO as the sole representative of the Palestinian people in 1974. For more, see Cleveland and Bunton, History of the Modern Middle East.

41 Yezid Sayigh, Armed Struggle and the Search for State: The Palestinian National Movement, 1949-1993 (New York: Oxford University Press, 1997).

42 Gerard Chaliand and Arnaud Blin, The History of Terrorism From Antiquity to Al Qaeda (Berkeley: University of California Press, 2007).

43 Ibid.

44 Cleveland and Bunton, History of the Modern Middle East.

45 Robins, A History of Jordan.

46 Charles Winslow, Lebanon: War and Politics in a Fragmented Society (London: Routledge, 1996); Berti, The Ongoing Battle for Beirut.

47 Laurie Eisenberg, "History Revisited or Revamped? The Maronite Factors in Israel's 1982 Invasion of Lebanon,” in Conflict, Diplomacy and Society in Israeli-Lebanese Relations, ed. Efraim Karsh, Michael Kerr, and Rory Miller (London: Routledge, 2010), 54-78. The security zone was an area constituting about $10 \%$ of Lebanon's territory that after 1982 had been under the military control of the IDF, with the assistance of the Southern Lebanese Army, a Christian militia that acted as an Israeli proxy in the occupied areas. See Augustus Richard Norton and Jillian Schwedler, “(In)security Zones in South Lebanon,” Journal of Palestine Studies 23, no. 1 (1993): 61-79.

48 The Taif Agreement was signed on October 22, 1989, and ratified on November 4, 1989.

49 Naim Qassem, Hizbullah: The Story From Within (London: Saqi, 2005).

50 Augustus Richard Norton, "Changing Actors and Leadership Among the Shiites of Lebanon," Annals of the American Academy of Political and Social Science 482, no. 1 (1985): 109-121.

51 Ahmad Nizar Hamzeh, In the Path of Hizbullah (Syracuse: Syracuse University Press, 2004).

52 Martin Kramer, "Hizbullah: The Calculus of Jihad," Bulletin of the American Academy of Arts and Sciences 47, no. 8 (1994): 20-43; Augustus R. Norton, Hezbollah (Princeton: Princeton University Press, 2007).

53 Michael Horowitz, The Diffusion of Military Power: Causes and Consequences for International Politics (Princeton: Princeton University Press, 2010), 174-176.

54 Benedetta Berti, Armed Political Organizations: From Conflict to Integration (Washington, DC: Johns Hopkins University Press, 2013).

55 Ibid.

56 Iver Gabrielsen, "The Evolution of Hezbollah's Strategy and Military Performance, 1982-2006," Small Wars and Insurgencies 25, no. 2 (2014): 257-283.

57 Ralph Peters, "Lessons from Lebanon: The New Model Terrorist Army," Armed Forces Journal International 144, no. 3 (2006): 38-43.

58 Stephen Biddle and Jeffrey A. Friedman, The 2006 Lebanon Campaign and The Future of Warfare: Implications for Army and Defense Policy (Carlisle: Strategic Studies Institute, 2008), 52.

59 David E. Johnson, Hard Fighting: Israel in Lebanon and in Gaza (Santa Monica: RAND, 2011).

60 Richard Beeston and Nicholas Blanford, "Hezbollah Stockpiles 40,000 Rockets Near Israel Border," The Times, August 5, 2009, www.thetimes.co.uk/article/hezbollah-stockpiles-40000-rockets-near-israel-border-wdx776ph8qp; Jeffrey White, If War Comes: Israel vs. Hizballah and Its Allies (Washington, DC: The Washington Institute, 2010).

61 Jeffrey White, "Hizb Allah at War in Syria: Forces, Operations, Effects and Implications," CTC Sentinel 7, no. 1 (2014): 14-17.

62 The term "first intifada" refers to the cycle of organized protests beginning in December 1987. It is commonly understood to have concluded when the Oslo Accords were signed on September 13, 1993. See Mary E. King, "Palestinian Civil Resistance Against Israeli Military Occupation," in Civilian Jihad: Nonviolent Struggle, Democratization, and Governance in the Middle East, ed. Maria J. Stephan (New York: Palgrave Macmillan, 2009), $131-156$. 


\section{Benedetta Berti}

63 Itamar Rabinovich, Waging Peace: Israel and the Arabs, 1948-2003 (Princeton: Princeton University Press, 2004).

64 Ibid.

65 Berti, Armed Political Organizations.

66 International Crisis Group, Enter Hamas: The Challenge of Political Integration (Brussels: International Crisis Group, 2006).

67 Johnson, Hard Fighting.

68 Yoram Cohen and Jeffrey White, Hamas in Combat: The Military Performance of the Palestinian Islamic Resistance Movement (Washington, DC: The Washington Institute, 2009); Eitan Shamir and Eado Hecht, "Gaza 2014: Israel's Attrition vs Hamas' Exhaustion," Parameters 44, no 4 (2014): 81-90. 